\title{
Research.
}

\section{THE RELATIONSHIP BETWEEN TRANSFORMATIONAL LEADERSHIP, TRAINING, AND EMPLOYEE INVOLVEMENT AS AN INTERVENTION VARIABLE ON EMPLOYEE PERFORMANCE}

\author{
David Oloan Sitorus*) \\ Faculty of Economics and Business, Universitas Esa Unggul, Special Capital Region of \\ Jakarta, Indonesia \\ davidoloan0804@gmail.com \\ * Corresponding author
}

Received: October 13, 2021 Accepted: November 10, 2021 Published: December 31, 2021

To cite this article: Sitorus, DO. (2021). The Relationship Between Transformational Leadership, Training, And Employee Involvement As An Intervention Variable On Employee Performance. The Management Journal Of Binaniaga, 6 (2), 151- 164 . doi:10.33062/mjb.v6i2.462

ABSTRACT. This research is useful for examining the effects and relationships of the three variables, namely transformational leadership, training, and employee engagement on employee performance. The sample taken for this research amounted to 175 respondents who were selected randomly. The analytical method used in this research is Lisrel's Structural Equation Modeling (SEM) analysis. The results of the research show that transformational leadership does not directly affect employee performance, good training affects employee performance directly, and good employee involvement does not directly affect employee performance. According to the research results, the researcher gives advice to companies to be able to improve employee performance and ensure and comply with regulations in accordance with applicable law in an agency. The uniqueness of this research is that the researcher takes the variable regarding Employee Engagement in the construction industry (Real Estate) which has not been studied by many previous researchers.

Keywords: transformational leadership, training, employee engagement, employee performance, building industry.

\section{INTRODUCTION}

In all organizations, both private and public, have goals that can be achieved by using all available resources to carry out the work. The success of the company can be seen from the way the company uses its resources. One of the important factors for the company's success is human resources. This is because human resources can contribute to good abilities, education, and skills in facing company challenges. To realize the company's big goals, it takes employees who have a high commitment to the company. So, every company must be able to improve the quality of its resources to improve the performance of its employees. In today's civilization,

Employee performance is a multidimensional phenomenon that has a vital role in determining the success and failure of an organization. Employees can be considered as the blood that flows in a company, and can be considered the most valuable asset for any company because they can advance or destroy a company's reputation and have an impact on company profits. Lutwama (2011) concludes that developing countries experience poor employee performance and this is because of minimal employee involvement.

Bagyo (2013) stated that previous research indicated that there are factors that influence the performance of an employee in a company, namely employee involvement and leadership traits. Imran (2013) determined that training is a human resource management practice that has a vital role positively and affects the quality of skills,

David Oloan Sitorus. The Relationship Between Transformational Leadership, Training, and Employee Involvement as an Intervention Variable on Employee Performance 
knowledge, and abilities of workers in producing better performance in the workplace. Employee training in an organization can produce substantial productivity and quality performance (Kiweewa \& Asiimwe, 2014). In addition, according to Amin et al. (2013) in his research found that employees who are given training, their level of commitment and knowledge will increase, which will have an impact on performance improvement. Men (2015) argues that employees who are involved in a company can be characterized by energy, dedication, enthusiasm and progress that have a positive impact on increasing their performance. The last few years have witnessed that transformational leadership and charismatic leadership are very important aspects of leadership related to individual performance in the company. Leadership effectiveness measures the leader's ability to encourage his subordinates to achieve common goals. The last few years have witnessed that transformational leadership and charismatic leadership are very important aspects of leadership related to individual performance in the company. Leadership effectiveness measures the leader's ability to encourage his subordinates to achieve common goals. The last few years have witnessed that transformational leadership and charismatic leadership are very important aspects of leadership related to individual performance in the company. Leadership effectiveness measures the leader's ability to encourage his subordinates to achieve common goals.

Many researches on employee performance have been conducted, but not many have examined the contribution of training and employee involvement as mediators in employee training relationships in developing countries such as Indonesia. The desire to contribute to employee training and involvement on employee performance in Indonesia in the construction industry formed the motivation of researchers to conduct this research. This can be achieved by distributing a questionnaire survey to more than 150 respondents in a company located in Jakarta. This research is important for the future because it contributes to the existing literature by examining the contribution of training and employee engagement and examining the mediating effect of employee engagement with employee training on employee performance. This research was conducted to analyze and explain that transformational leadership significantly affects and affects employee performance in a contracting company, analyzes and explains that employee training significantly affects employee performance in a contracting company, analyzes and explains that employee involvement has a significant effect and affects employee performance. in a contracting company. According to Hasibuan (2010), a leader is someone who uses his authority to direct others and is responsible for that person's work in achieving organizational goals. The leadership applied by a leader in an organization has different characteristics. These characteristics are often referred to as leadership styles.

Transformational leadership can be defined as the quality of someone who inspires subordinates or co-workers to achieve common goals, besides transformational leadership can be defined as the ability of an individual to motivate co-workers or subordinates to provide better performance (Robbins, 2013). by Tania (2017) says that transformational leadership has four main elements that a person must have, namely: (1) Intellectual Stimulation, where those who have a transformational leadership figure are able to open opportunities for each member to continue to learn and be creative and proactive in exploring new ways. in generating innovation in its members. (2) Individual Considerations, is an element possessed by a leader to be able to understand each of its members and be able to provide support and appreciation for the achievements obtained. (3) Inspirational Motivation, is an element that tends to act as a mentor to assist its members by providing guidance and challenges that aim to hone the potential within its members. In addition, this element has a duty to always generate optimism, motivation, and enthusiasm for each member. (4) Influence Idealization, is an element that focuses on building a corporate culture where every member is willing to work together for the common good. With the mentoring efforts mentioned earlier, a leader will transmit his passion to all his subordinates. And in the process of reciprocity,

Transformational leadership describes a process in which a leader tries to bring out the hidden positive things in an individual or group by providing inspiration and vision and motivating followers to change their personal interests into common interests (Avolio et

David Oloan Sitorus. The Relationship Between Transformational Leadership, Training, and Employee Involvement as an Intervention Variable on Employee Performance 
al., 2013). Basically, Indonesian people generally prefer spoken language to written language in communicating. So, sharing knowledge through personalization is nothing new. In practice, the habit of sharing knowledge is better done directly orally, such as holding open meetings, not by giving writings that are not easy to understand. In this research, Researchers focus more on interpersonal determinants that affect knowledge sharing, namely transformational leadership and its impact on employee performance.

In developing the ability of an employee, a training is a means of motivation that can encourage and improve the ability of an employee for the better, which is intended to improve the performance of the employee. In a human resource, a concept of training has a high popularity because it provides a positive relationship with employee performance (Kiweewa \& Asiimwe, 2014). Training is an aspect that helps an individual to achieve his goals and objectives and improve his performance (Tahir et al., 2014).

In addition, training has a relationship with motivation which is a series of forces that initiate, direct and maintain a person in an effort to achieve goals (Luthans, 2012). A training focused on improving the skills and knowledge of an employee, which in turn will improve the employee's performance (Azeem et al., 2013). One way to increase the productivity of employees is by conducting training. In a training process, an employee will receive in-depth knowledge, technical and interpersonal skills and skills to do his job effectively and efficiently (Nawaz et al., 2014). A training not only builds the ability of an employee but also sharpens their thinking ability and creativity to make better decisions (Sharma \& Taneja, 2018). Therefore, it can be concluded that training is a process of delivering skills, attitudes, discipline, and giving skills to employees according to the field of work they will be involved in.

Engagement has been conceptualized in various ways, for example, according to Men (2015) it is a positive attitude and behavior that an employee has towards a company. An employee's performance can be measured by the level of commitment of an employee to the organization (Selvarasu \& Sastry, 2014). In an agency, employees who are involved in the agency and understand the context and work will work together with colleagues to improve performance in their work to provide the best results for the agency (Andrew \& Sofian, 2012).

According to (Shantz et al., 2013), employees who are involved in a group who have positive attitudes and behaviors and work mindsets with characteristics such as enthusiasm, dedication, and good absorption will minimize the occurrence of errors in the work. To improve the performance of an employee, an organization conducts training and empowerment for these employees (Ariani, 2013). In other words, employees who receive various benefits such as training and resources from an organization will have a sense of returning the favor of the organization through greater work involvement and show better attitudes and behaviors (Otieno et al., 2015).

Generally, companies are founded with the aim of achieving certain profits with minimal costs. To be able to carry out the company's activities in accordance with the plan, various factors of production are needed, which include capital, labor, natural resources and expertise. In order to achieve the goals that have been set by the company so that it can be achieved properly, every company is obliged to manage these production factors effectively and efficiently. In a Research conducted by Pawirosumarto et al. (2017), performance is an overall result or success of a person during a certain task period compared to work standards, targets or criteria that have been previously determined and have been agreed upon. Employee performance will not be able to provide optimal results if they only rely on production equipment without paying attention to the human aspect. which can result in harm to employees and the company. Employees with accountable skills have the ability to complete everything, taking into account what he produces and working responsibly. then the workforce will be better able to accept the tasks given by the company properly and of course will reduce the risk that can result in harming employees and the company. Employees with accountable skills have the ability to complete everything, taking into account what he produces and working responsibly. then the workforce will be better able to accept the tasks given by the company properly and of course will reduce the risk that can result in harming

David Oloan Sitorus. The Relationship Between Transformational Leadership, Training, and Employee Involvement as an Intervention Variable on Employee Performance 
employees and the company. Employees with accountable skills have the ability to complete everything, taking into account what he produces and working responsibly.

In previous researches, transformational leadership has a relationship with employee performance (Avolio et al., 1991). Meanwhile, employee training and employee involvement also have an influence on employee performance according to research conducted by Sharma (2018) and Wahyu Ariani (2013). Previous studies have conducted and studied training interventions with other variables, such as employee engagement. The previous research studied demographic factors such as gender, where the sample was taken, and so on.

Exploration related to the effect of employee training and employee involvement as an intervention variable has not been widely conducted by previous researchers. Thus, on the basis of these considerations this research considers using employee involvement as an intervention variable and has an influence on employee performance and is conducted in a different industry from previous studies (Otieno et al., 2015). Currently, as a result of employee demands, the development of employee performance is getting better and more advanced. In addition, previous research conducted more research using industries such as banking, while in this research, it was conducted using data obtained from companies engaged in the property sector.

Research conducted by Thamrin (2012) describes specific behaviors related to transformational leadership, including being a model who has integrity and fairness, can set clear goals, have high expectations, provide support and encouragement to those around him, move people's emotions and passions. the people around him, and make the people around him leave their personal interests and achieve common goals. In addition, a research conducted by Hasibuan (2010) states that someone who has the ability to have transformational leadership traits will always have a new vision and way of thinking about strategy, structure, change, innovation, and has an entrepreneurial perspective. Hasibuan (2010) also believes that transformational leadership is a systematic process that can be learned.

\section{$\mathrm{H}_{1}$ : Transformational Leadership affects Employee Performance}

In previous researches, training provides evidence that there is a strong positive relationship between performance and training. Sharma \& Taneja (2018) state that training is one of the vital resource management practices that positively affects the quality of an employee's knowledge and abilities, leading to an increase in the employee's performance. According to Hameed (2011) an employee who has good training and has high motivation can work without needing to be supervised because of the ability and confidence they have. Through planned training, workers will become more productive and skilled and gain new abilities to help achieve current and future goals.

\section{$\mathrm{H}_{2}$ : Training affects Employee Performance}

In a research conducted by Shantz et al. (2013) argue that through training, Job Engagement is increased by promoting a positive attitude characterized by passion, dedication, and absorption. According to Nawaz et al. (2014), employees show engaged behavior when they are given training and empowerment, so engagement is related to giving effort at work and being persistent when facing difficulties. Thus, it can be seen that when an organization takes care of its employees through training and empowerment, the employees will further improve their behavior in their work, so that they will get better performance.

\section{$\mathrm{H}_{3}$ : Employee Engagement affects Employee Performance \\ $\mathrm{H}_{4}$ : Employee Engagement has an intervention relationship with Employee Training and Performance.}

David Oloan Sitorus. The Relationship Between Transformational Leadership, Training, and Employee Involvement as an Intervention Variable on Employee Performance 


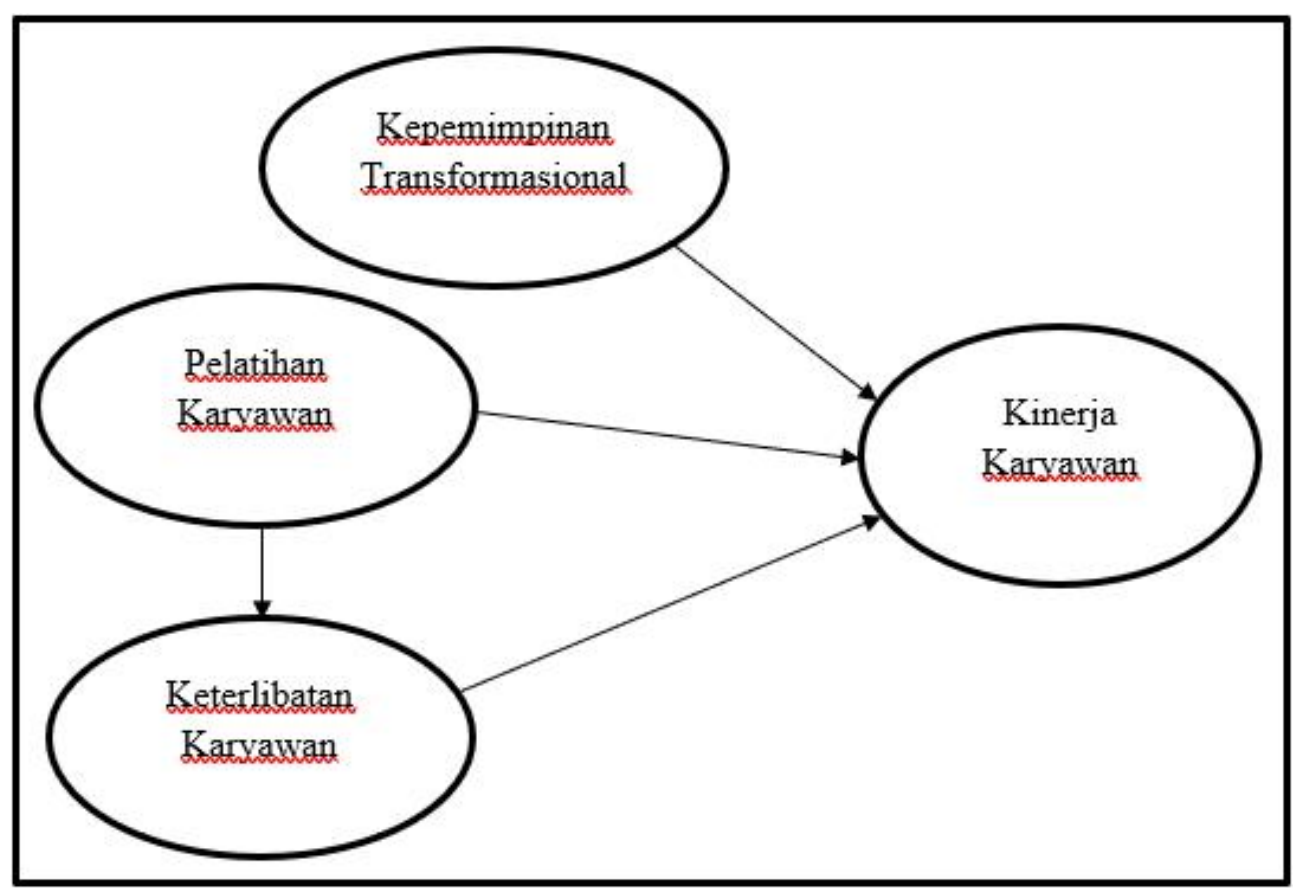

Figure 1 Research Model

\section{RESEARCH METHODS}

This research was conducted on permanent employees at PT Bumimas Megah Prima in December 2018 with the research method being causality model analysis to see the relationship between variables. Companies engaged in the property industry were chosen as research objects because this industry is rarely used as an object of research, but this industry is an industry that has rapid development. The aspect studied is Transformational Leadership. The data analysis method in this research used Structural Equation Modeling (SEM). The sampling technique used in this research is According to the availability and convenience of the elements obtained. The number of samples used in this research was adjusted to the analytical method used, namely Lisrel's Structural Equation Model (SEM). In the SEM method, the number of samples required is at least 5 times the number of variables. The data measurement method uses a Likert scale with a scale interval of one to four. The results of the analysis are then interpreted and the final step is concluded and suggestions are given.

This research uses 3 independent variables and 1 dependent variable. The questionnaire used has been pre-tested on 30 respondents to test the validity and reliability of the questionnaire. The transformational leadership variable uses research conducted by Warrick (2011), the training variable uses research conducted by Ensour et al. (2018), employee engagement variables use research conducted by Littman-Ovadia \& Balducci (2013) and employee performance variables use research conducted by Hogan (2005). In research conducted by Field (2009) stated that validity in a Research is an Evidence that the contents of the research are in accordance with the constructs that have been designed and discussed.

David Oloan Sitorus. The Relationship Between Transformational Leadership, Training, and Employee Involvement as an Intervention Variable on Employee Performance 
The Management Journal of BINANIAGA Vol. 06, No.02, December 2021

p-ISSN: 2527 - 4317, e-ISSN: $2580-149 x$

$6^{\text {th }}$ Accreditation Rating: April 04, $2019-$ April 03, 2024

Table 1 Table of KMO \& Alpha Cronbach

\begin{tabular}{|c|c|c|c|}
\hline Research Variables & Dimension & $\begin{array}{c}\text { Kaiser-Meyer-Olkin } \\
\text { (KMO) }\end{array}$ & $\begin{array}{l}\text { Alpha's } \\
\text { Chronbach }\end{array}$ \\
\hline \multirow{3}{*}{$\begin{array}{c}\text { Transformational } \\
\text { Leadership (Warrick, 2011) }\end{array}$} & Leading. & 0.652 & 0.721 \\
\hline & $\begin{array}{l}\text { Championing } \\
\text { Changes. }\end{array}$ & 0.572 & 0.672 \\
\hline & $\begin{array}{l}\text { Transforming } \\
\text { Organizations. }\end{array}$ & 0.547 & 0.747 \\
\hline \multirow{3}{*}{$\begin{array}{c}\text { Training (Ensour et al., } \\
\text { 2018) } \\
\end{array}$} & Valence. & 0.503 & 0.853 \\
\hline & Instrumentaly. & 0.681 & 0.658 \\
\hline & Expectancy. & 0.701 & 0.774 \\
\hline \multirow{3}{*}{$\begin{array}{c}\text { Employee Engagement } \\
\text { (Littman-Ovadia \& } \\
\text { Balducci, 2013) }\end{array}$} & Vigor. & 0.616 & 0.718 \\
\hline & Dedication. & 0.541 & 0.744 \\
\hline & Absorption. & 0.734 & 0.839 \\
\hline \multirow{7}{*}{$\begin{array}{l}\text { Employee Performance } \\
\text { (Thamrin, 2012) }\end{array}$} & Quantity of Work. & 0.694 & 0.701 \\
\hline & Quality of Work. & 0.600 & 0.611 \\
\hline & Cooperation. & 0.577 & 0.755 \\
\hline & Attendance. & 0.653 & 0.888 \\
\hline & Initiative. & 0.730 & 0.674 \\
\hline & Job Knowledge. & 0.552 & 0.754 \\
\hline & Reliability. & 0.725 & 0.712 \\
\hline
\end{tabular}

The instrument used to measure the transformational leadership variable has 3 dimensions According to research conducted by Warrick (2011), namely; Leading, Championing Changes, \& Transforming Organizations with their operational definition, namely employees feel a clear picture of what must be done and the reasons why it must be done and the goals of a leader provide examples and reasons why leaders motivate their members to face the challenges given. Furthermore, the instrument used to measure the employee training variable has 3 dimensions According to research conducted by Ensour et al. (2018), namely; Valence, Instrumentaly, \& Expectancy with its operational definition, namely providing training to employee members, then employees will feel that they are company assets that are well guarded, so that a feeling arises within the employee members to take part in training which will ultimately increase the technical and practical knowledge of employees and strengthen skills in solving problems in accordance with the employee's field. In addition, by providing training, employees will gain new skills as a provision for the future of these employees. In addition, the instrument used to measure the employee engagement variable has 3 dimensions According to research conducted by Littman-Ovadia (2013), namely; Vigor, Dedication, \& Absorption with its operational definition, that is, employees feel highly enthusiastic and enthusiastic about their work and get inspiration from where the employee works.

Finally, there are 7 instruments used to measure the last variable in this research conducted by Thamrin (2012), namely the employee performance variable. The instruments are; Quality of Work, Quantity of Work, Cooperation, Attendance, Initiative, Job Knowledge, \& Reliability. Each with its operational definition, namely; employees can produce a consistent volume of work and in accordance with the standards created, can consistently produce accurate and precise work, understand the applicable rules so that coworkers are respected and liked by superiors, maintain good attendance and punctuality, carry out their work properly. minimal intervention, understand applicable technical and operational procedures, and follow policies in carrying out their work.

David Oloan Sitorus. The Relationship Between Transformational Leadership, Training, and Employee Involvement as an Intervention Variable on Employee Performance 
Table 2 Table of Questionnaire Instruments

\begin{tabular}{|c|c|c|c|c|}
\hline \multicolumn{5}{|c|}{ Transformational Leadership (Warrick, 2011) } \\
\hline No & Dimension & Original & Translation & Context \\
\hline 1. & Leading & $\begin{array}{l}\text { Vision. A clear and } \\
\text { compelling picture } \\
\text { of what needs to be } \\
\text { done and why. }\end{array}$ & & $\begin{array}{l}\text { My superior has a } \\
\text { clear view of the } \\
\text { vision to be } \\
\text { achieved. }\end{array}$ \\
\hline 2. & & $\begin{array}{l}\text { Direction. Clear } \\
\text { goals, values, and } \\
\text { priorities. }\end{array}$ & & $\begin{array}{l}\text { My superior } \\
\text { provides clear } \\
\text { values, goals, and } \\
\text { priorities. }\end{array}$ \\
\hline 3. & & $\begin{array}{l}\text { Inspiration. Leading } \\
\text { by example and } \\
\text { motivating people to } \\
\text { excel, meet the } \\
\text { challenge, and } \\
\text { presevere. }\end{array}$ & & $\begin{array}{l}\text { My superior leads } \\
\text { and motivates co- } \\
\text { workers to } \\
\text { persevere in facing } \\
\text { challenges. }\end{array}$ \\
\hline 4. & $\begin{array}{l}\text { Championing } \\
\text { Change }\end{array}$ & $\begin{array}{l}\text { Initiating Change. } \\
\text { Skills in leading or } \\
\text { sponsoring needed } \\
\text { change. }\end{array}$ & & $\begin{array}{l}\text { My superior lead } \\
\text { me and support the } \\
\text { changes needed. }\end{array}$ \\
\hline 5. & & $\begin{array}{l}\text { Facilitating Change. } \\
\text { Skills in guiding or } \\
\text { paving the way for } \\
\text { change. }\end{array}$ & & $\begin{array}{lr}\text { My superior leads } \\
\text { me and co-workers } \\
\text { towards } \quad \text { better } \\
\text { changes. }\end{array}$ \\
\hline 6. & & $\begin{array}{l}\text { Implementing } \\
\text { Change. Skills in } \\
\text { designing, } \\
\text { managing, and } \\
\text { sustaining changes. }\end{array}$ & & $\begin{array}{l}\text { My superior } \\
\text { designs, manages, } \\
\text { and sustains } \\
\text { change. }\end{array}$ \\
\hline 7. & $\begin{array}{l}\text { Transforming } \\
\text { Organizations }\end{array}$ & $\begin{array}{l}\text { Knowing Present } \\
\text { Realities. Skills in } \\
\text { being keenly aware } \\
\text { of internal and } \\
\text { external realities. If } \\
\text { you know reality } \\
\text { you can almost } \\
\text { always do } \\
\text { something about it. }\end{array}$ & & $\begin{array}{l}\text { My superior is } \\
\text { aware of the current } \\
\text { internal and } \\
\text { external realities. }\end{array}$ \\
\hline 8. & & $\begin{array}{l}\text { Identifying Future } \\
\text { Ideals. Skills in } \\
\text { being aware of best } \\
\text { practices and } \\
\text { clearly defining and } \\
\text { communicating } \\
\text { future ideals. If you } \\
\text { know and can } \\
\text { define what is } \\
\text { possible you can } \\
\text { probably build it. }\end{array}$ & & $\begin{array}{l}\text { My superior knows } \\
\text { the best way to } \\
\text { come up with ideas } \\
\text { for the future. }\end{array}$ \\
\hline 9. & & 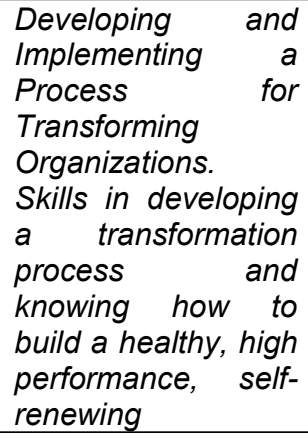 & & $\begin{array}{l}\text { My superior is } \\
\text { capable of } \\
\text { developing and } \\
\text { building a healthy, } \\
\text { independent, and } \\
\text { high-performing } \\
\text { company. }\end{array}$ \\
\hline
\end{tabular}

David Oloan Sitorus. The Relationship Between Transformational Leadership, Training, and Employee Involvement as an Intervention Variable on Employee Performance 
The Management Journal of BINANIAGA Vol. 06, No.02, December 2021 p-ISSN: $2527-4317$, e-ISSN: $2580-149 x$

$6^{\text {th }}$ Accreditation Rating: April 04, $2019-$ April 03, 2024

\begin{tabular}{|c|c|c|c|c|}
\hline & & organization. & & \\
\hline \multicolumn{5}{|c|}{ Employee Training (Ensour et al., 2018) } \\
\hline No & Dimension & Original & Translation & Context \\
\hline 1. & Valence & $\begin{array}{l}\text { By attending } \\
\text { training activities, I } \\
\text { want to improve } \\
\text { technical/practical } \\
\text { knowledge in my } \\
\text { job. }\end{array}$ & & $\begin{array}{l}\text { Training increases } \\
\text { technical and field } \\
\text { knowledge in my } \\
\text { work. }\end{array}$ \\
\hline 2. & & $\begin{array}{l}\text { I feel that it is } \\
\text { important to take } \\
\text { part in training } \\
\text { programs in order to } \\
\text { strengthen my } \\
\text { problem-solving } \\
\text { skill. }\end{array}$ & & $\begin{array}{l}\text { Training } \\
\text { strengthened my } \\
\text { problem-solving } \\
\text { skills. }\end{array}$ \\
\hline 3. & & $\begin{array}{l}\text { I think it is important } \\
\text { to learn new things } \\
\text { from training } \\
\text { activities. }\end{array}$ & & $\begin{array}{l}\text { Training taught me } \\
\text { new things for my } \\
\text { job. }\end{array}$ \\
\hline 4. & Instrumentality & $\begin{array}{l}\text { I believe that } \\
\text { training activity is } \\
\text { useful for workers } \\
\text { who occupy a job } \\
\text { position similar to } \\
\text { mine. }\end{array}$ & & $\begin{array}{l}\text { Training is useful } \\
\text { for employees with } \\
\text { similar job } \\
\text { positions. }\end{array}$ \\
\hline 5. & & $\begin{array}{l}\text { Usually, I am able } \\
\text { to apply to my job } \\
\text { what I learn in } \\
\text { training activities. }\end{array}$ & & $\begin{array}{l}\text { Training makes it } \\
\text { easy to apply for } \\
\text { the right job. }\end{array}$ \\
\hline 6. & & $\begin{array}{l}\text { Acquiring new skills, } \\
\text { thanks to training } \\
\text { activities, positively } \\
\text { influences my } \\
\text { performances. }\end{array}$ & & $\begin{array}{l}\text { Training affected } \\
\text { my performance in } \\
\text { a positive way. }\end{array}$ \\
\hline 7. & Expectancy & $\begin{array}{l}\text { If I am involved in } \\
\text { training activities, I } \\
\text { am confident I can } \\
\text { master aspects of } \\
\text { my job. }\end{array}$ & & $\begin{array}{l}\text { I can master my job } \\
\text { thanks to training. }\end{array}$ \\
\hline 8. & & $\begin{array}{l}\text { If I am involved in } \\
\text { training activities, I } \\
\text { am confident I can } \\
\text { learn the new } \\
\text { knowledge taught in } \\
\text { the training } \\
\text { activities. }\end{array}$ & & $\begin{array}{l}\text { I gained new } \\
\text { knowledge thanks } \\
\text { to training. }\end{array}$ \\
\hline 9. & & $\begin{array}{l}\text { If I am involved in } \\
\text { training activities, I } \\
\text { am confident I can } \\
\text { improve my ability } \\
\text { of initiative. }\end{array}$ & & $\begin{array}{l}\text { I can increase my } \\
\text { initiative thanks to } \\
\text { training. }\end{array}$ \\
\hline
\end{tabular}

Employee Engagement (Littman-Ovadia \& Balducci, 2013)

\begin{tabular}{lllll}
\hline No & Dimension & Original & Translation & Context \\
\hline 1. & Vigor & $\begin{array}{l}\text { At my work, I feel } \\
\text { bursting } \\
\text { energy. }\end{array}$ & with & $\begin{array}{l}\text { I feel full of energy } \\
\text { at my workplace. }\end{array}$ \\
\hline 2. & At my job, I feel & I feel strong and \\
\hline
\end{tabular}

David Oloan Sitorus. The Relationship Between Transformational Leadership, Training, and Employee Involvement as an Intervention Variable on Employee Performance 
The Management Journal of BINANIAGA Vol. 06, No.02, December 2021

p-ISSN: $2527-4317$, e-ISSN: $2580-149 x$

$6^{\text {th }}$ Accreditation Rating: April 04, 2019 - April 03, 2024

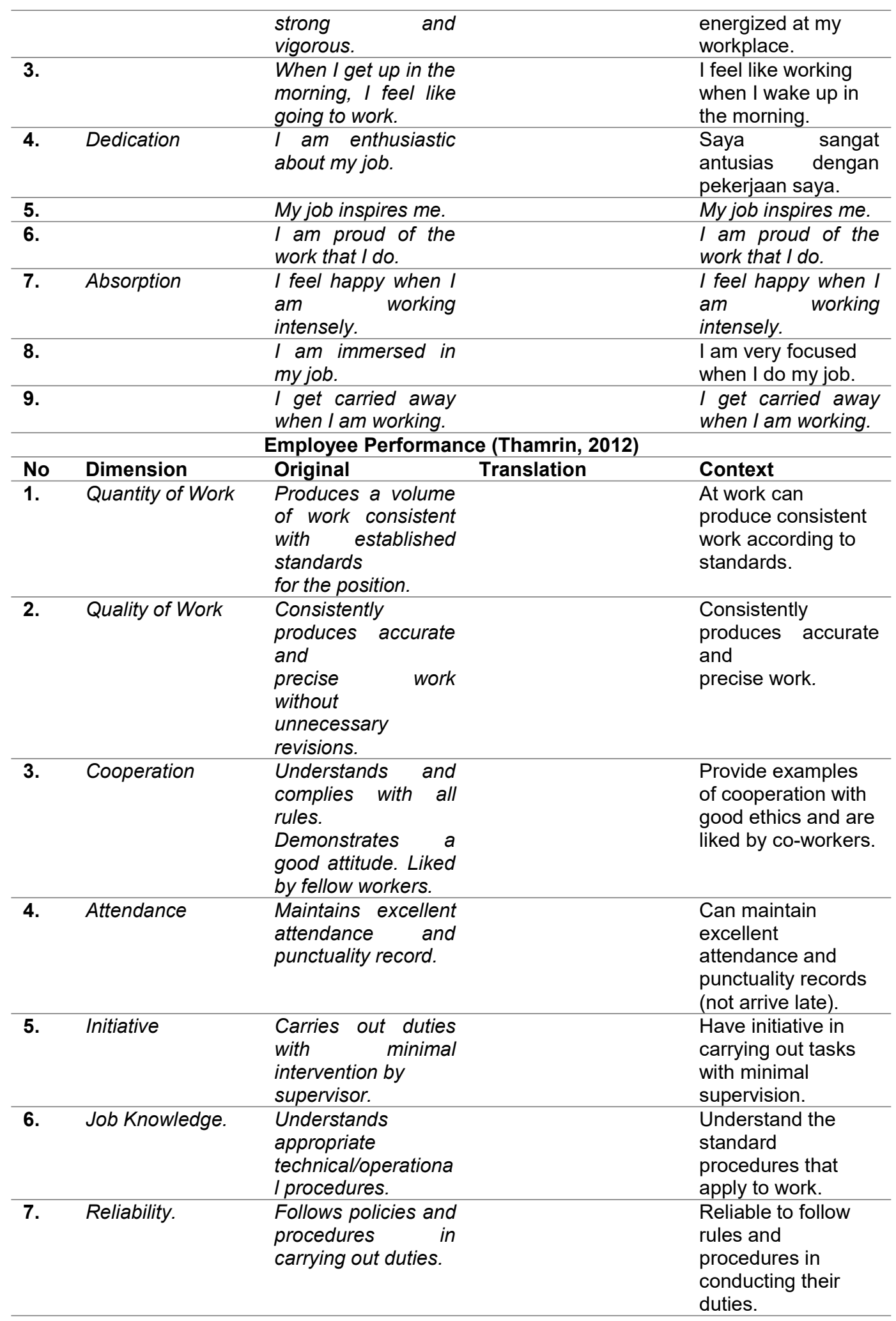

Field (2009) defines reliability as the ability of a measurement to produce consistent test results when the same entity is measured under different conditions. Validity test is done by Confirmatory Factor Analysis by looking at the values of Kaiser-Meyer-Olkin Measure of Sampling (KMO) and Measures of Sampling Adequacy

David Oloan Sitorus. The Relationship Between Transformational Leadership, Training, and Employee Involvement as an Intervention Variable on Employee Performance 
(MSA). In this test, the value obtained must be greater than 0.5 , which means that factor analysis is appropriate or appropriate to use, and can be further processed using Lisrel 88 to test and analyze the Structural Equation Model (SEM). The SEM model is a model that combines factor analysis approaches, path analysis, and structural models simultaneously.

\section{RESULTS AND DISCUSSION}

The purpose and focus of this research to examine the relationship of the variables of transformational leadership, employee training, and employee involvement to the variables of employee performance. Where from the three hypotheses that have been proposed, data is obtained that supports that the hypothesis is accepted or not.

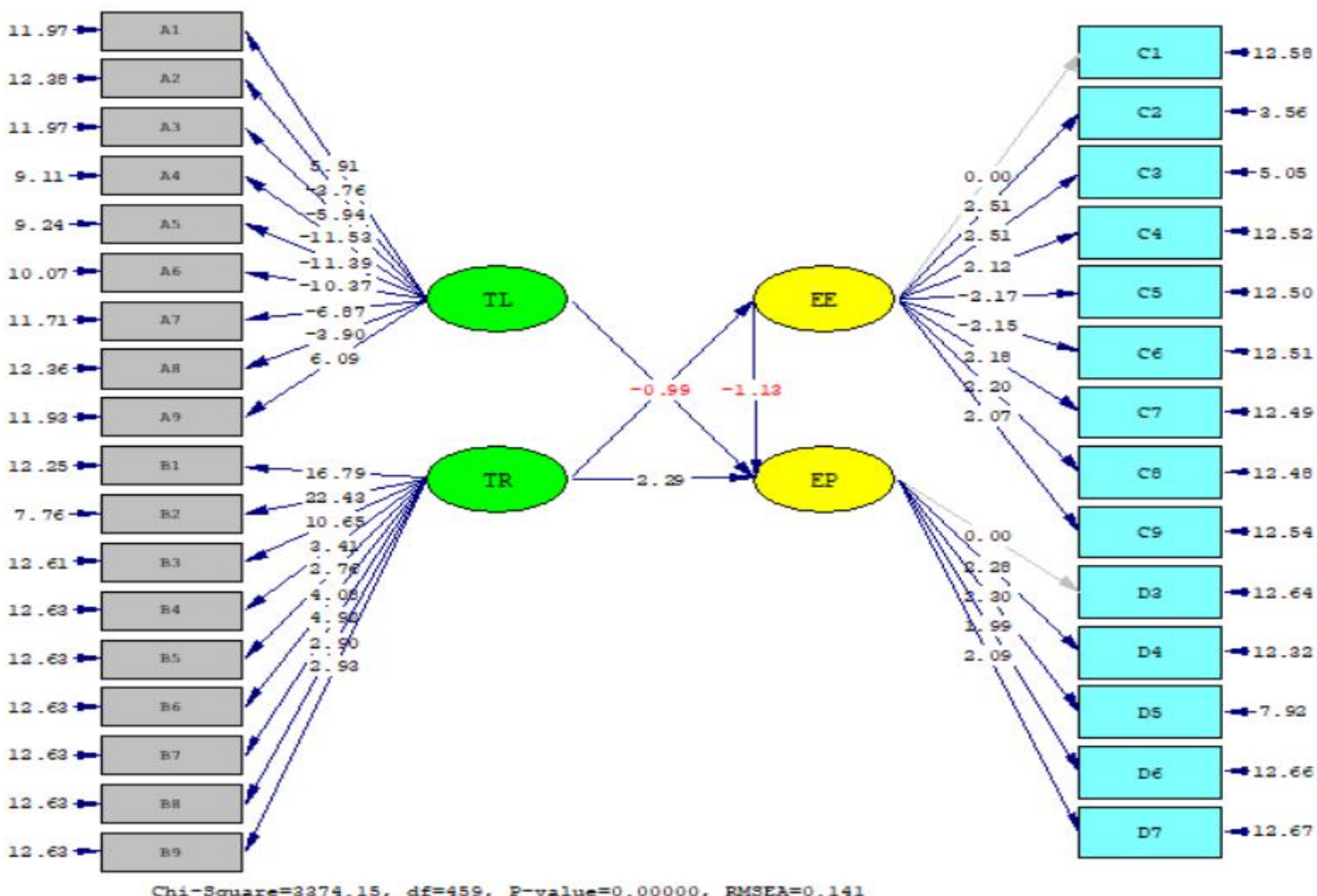

Figure 2 Path Diagram (t-Value)

According to the diagram above, the hypotheses in this research are:

Table 3 Hypothesis Testing

\begin{tabular}{clccc}
\hline Hypothesis & Hypothesis Statement & $\begin{array}{l}\text { t-Value } \\
\text { Score }\end{array}$ & Remarks \\
\hline $\mathbf{H}_{\mathbf{1}}$ & $\begin{array}{l}\text { Transformational Leadership } \\
\text { Employee Performance. }\end{array}$ & affects & $-0.99 \quad \begin{array}{l}\text { Data tidak mendukung } \\
\text { hipotesis. }\end{array}$
\end{tabular}

David Oloan Sitorus. The Relationship Between Transformational Leadership, Training, and Employee Involvement as an Intervention Variable on Employee Performance 


\begin{tabular}{llll}
\hline $\mathbf{H}_{2} \quad$ Training affects Employee Performance. & $2.29 \begin{array}{l}\text { Data } \\
\text { Hipotesis. }\end{array}$ \\
\hline $\mathbf{H}_{3} \quad \begin{array}{l}\text { Employee Engagement affects Employee } \\
\text { Performance. }\end{array}$ & -1.12 & $\begin{array}{l}\text { Data tidak mendukung } \\
\text { hipotesis. }\end{array}$ \\
\hline $\mathbf{H}_{4} \quad \begin{array}{l}\text { Employee Engagement has an } \\
\text { intervention relationship with Training and } \\
\text { Employee Performance. }\end{array}$ & $\begin{array}{l}\text { Data tidak mendukung } \\
\text { hipotesis. }\end{array}$ \\
\hline
\end{tabular}

The results of testing the first hypothesis $\left(\mathrm{H}_{1}\right)$, state that the results of the research analysis that have been conducted do not support the $\mathrm{H}_{1}$ hypothesis, namely Transformational Leadership does not affect Employee Performance with a t-Value value of -0.99 . The results of this research are not in line with a research conducted by Tania (2017) which states that someone who has the ability to have transformational leadership traits will always have new visions and ways of thinking about strategy, structure, change, innovation, and have an entrepreneurial perspective and better leadership. transformational applied by the leadership, the higher the employee's performance.

The results of testing the second hypothesis $\left(\mathrm{H}_{2}\right)$, state that the results of the research analysis that have been conducted support the hypothesis $\mathrm{H}_{2}$, namely good training affects employee performance of an employee in an organization or agency with a t-value of 2.99. The results of this research are in line with the research of Hameed (2011) which states that an employee when he has good training and has high motivation can work without needing to be supervised because of the ability and confidence they have.

The results of testing the third hypothesis $\left(\mathrm{H}_{3}\right)$, state that the results of the research analysis that have been conducted do not support the $\mathrm{H}_{3}$ hypothesis, namely that good employee engagement can affect employee performance with a t-value of -1.12. The results of this research are not in line with the research conducted by Shantz et al. (2013) which states that employees who are involved in an organization will have positive attitudes and behaviors and a working mindset with characteristics such as enthusiasm, dedication, and good absorption will minimize the occurrence of errors in the work.

The results of testing the third hypothesis $\left(\mathrm{H}_{4}\right)$, stated that the results of the research analysis that had been conducted did not support the $\mathrm{H}_{4}$ hypothesis, namely Employee Engagement has an intervention relationship with Training and Employee Performance with a t-Value value of -2.11 . The results of this research are also not in line with the research conducted by Nawaz et al. (2014) which states that employees display behaviors that are involved with an organization when they are given training and empowerment, then engagement is related to giving effort at work and being persistent when facing difficulties. Thus, it can be seen that when an organization takes care of its employees through training and empowerment, employees will further improve their behavior in their work, so they will get better performance.

\section{CONCLUSIONS AND SUGGESTIONS}

The results that can be concluded in this research are: (1) transformational leadership does not directly affect employee performance; (2) training directly affects employee performance; (3) employee involvement does not directly affect employee performance; (4) training does not directly affect employee performance when it is intervened by employee involvement.

The implications of this research are expected to have benefits for property companies in Jakarta, which will later be used as a form of reference and description of

David Oloan Sitorus. The Relationship Between Transformational Leadership, Training, and Employee Involvement as an Intervention Variable on Employee Performance 
human resources who work with transformational leadership, employee training, and employee involvement will affect employee performance. In the sustainability of the company, employees are an important asset so that the company can continue to run well and generate profits. In this research, it is expected that the company can improve the training that will be given to employees in order to better support the performance of these employees for the company.

In this research, there are limitations that are considered for further research. These limitations are as follows: (1) This research only examines one object of a company engaged in the property industry; (2) In filling out the questionnaire, respondents answered. According to the expected conditions not the actual conditions so that they did not give good results; (3) This research only examines one indicator, namely employee performance from many other indicators. This research has a small and limited scope because it only examines the variables of transformational leadership, employee training, employee engagement, and employee performance. For the development of further research, it is recommended to add other variables that have a relationship with employee performance such as career development, job satisfaction, and work motivation. For further research, it is expected to take samples with more than one company as the object so that the research results are more objective and have a broad scope.

\section{REFERENCES}

Achieng Otieno, B. B., Waiganjo, E. W., \& Njeru, A. (2015). Effect of Employee Engagement on Organisation Performance in Kenya's Horticultural Sector. International Journal of Business Administration, 6(2), 77-85.

Amin, A., Saeed, R., \& Lodhi, R. N. (2013). The Impact of Employees Training On the Job Performance in Education Sector of Pakistan. 17(9), 1273-1278.

Andrew, O. C., \& Sofian, S. (2012). Individual Factors and Work Outcomes of Employee Engagement. Procedia - Social and Behavioral Sciences, 40, 498-508.

Avolio, B. J., Kahai, S., \& Baker, B. (2013). E-leadership: Re-examining Transformations in Leadership Source and Transmission. The Leadership Quarterly.

Avolio, B. J., Waldman, D., \& Yammarino, F. J. (1991). Leading in the 1990s: The Four l's of Transformational Leadership. Journal of European Industrial Training, 15(4), 16.

Bagyo, Y. (2013). Engagement as a Variable to Improve the Relationship between Leadership , Organizational Culture on the Performance of Employees. 14(4), 1-8.

Ensour, W., Zeglat, D., \& Shrafat, F. (2018). Impact of job satisfaction on training motivation. Problems and Perspectives in Management, 16(3), 337-355.

Faisal Azeem, M., Rubina, \& Tahir Paracha, A. (2013). Connecting training and development with employee engagement: How does it matter? World Applied Sciences Journal, 28(5), 696-703.

Field, A. (2009). DISCOVERING STATISTICS USING SPSS. In Advances in Experimental Medicine and Biology, 622.

Hameed, Abdul, A. W. (2011). Employee empowerment of Lecturers. International Journal of Business and Social Sciences, 2(13), 224-229.

Hasibuan, M. (2010). Manajemen Sumber Daya Manusia. Bumi Aksara.

David Oloan Sitorus. The Relationship Between Transformational Leadership, Training, and Employee Involvement as an Intervention Variable on Employee Performance 
Hogan, R. L. (2005). Supervisors' Perception as a Measure of Training Transfer: A Predictive Validity Study of the Learning Transfer System Inventory.

Imran, A. (2013). The Effect of Training on Employee Performance. 5(4), 137-147.

Kiweewa, S. B., \& Asiimwe, S. B. (2014). Does training influence employee performance in regulatory organizations in Uganda? Empirical evidence from UCC. Merit Research Journal of Business and Management, 2(2), 21-29.

Littman-Ovadia, H., \& Balducci, C. (2013). Psychometric properties of the Hebrew version of the Utrecht work engagement scale (UWES-9). European Journal of Psychological Assessment, 29(1), 58-63.

Luthans, F. (2012). Organizational behavior an evidence-based approach 12th edition. In Organizational behavior: an edivence-based approach.

Lutwama, G. W. (2011). THE PERFORMANCE OF HEALTH WORKERS IN DECENTRALISED SERVICES IN UGANDA. JUne.

Men, L, R. (2015). Employee engagement in relation to employee-organization relationship and internal reputation: effects of leadership and communication. Public Relations Journal, 9(2), 11-22.

Men, L. R., \& Ph, D. (2015). Employee Engagement in Relation to Employee Organization Relationships and Internal Reputation: Effects of Leadership Communication. 9.

Nawaz, M. S., Hassan, M., Hassan, S., Shaukat, S., \& Asadullah, M. A. (2014). Impact of employee training and empowerment on employee creativity through employee engagement: Empirical evidence from the manufacturing sector of Pakistan. Middle - East Journal of Scientific Research, 19(4), 593-601.

Selvarasu, D., \& Subbu Krishna Sastry MBA Professor, N. (2014). A Study of Impact on Performance Appraisal on Employee's Engagement in an Organization. International Journal of Managerial Studies and Research, 2(11), 10-22.

Shantz, A., Alfes, K., Truss, C., \& Soane, E. (2013). The role of employee engagement in the relationship between job design and task performance, citizenship and deviant behaviours. International Journal of Human Resource Management, 24(13), 26082627.

Sharma, S., \& Taneja, M. (2018). The effect of training on employee performance. International Journal of Recent Technology and Engineering, 7(4), 6-13.

Stephen P, R., \& Timothy A, J. (2013). Organizational Behavior 15th Edition. Pearson Education.

Suharno Pawirosumarto, Purwanto Katijan Sarjana, \& Muzaffar Muchtar. (2017). Factors affecting employee performance of PT. Kiyokuni Indonesia. International Journal of Law and Management.

Tahir, N., Yousafzai, I. K., Yousafzai, I. K., Jan, D. S., \& Hashim, M. (2014). The Impact of Training and Development on Employees Performance and Productivity A case study of United Bank Limited Peshawar City, KPK, Pakistan. International Journal of Academic Research in Business and Social Sciences, 4(4).

David Oloan Sitorus. The Relationship Between Transformational Leadership, Training, and Employee Involvement as an Intervention Variable on Employee Performance 
The Management Journal of BINANIAGA Vol. 06, No.02, December 2021

p-ISSN: $2527-4317$, e-ISSN: $2580-149 x$

$6^{\text {th }}$ Accreditation Rating: April 04, $2019-$ April 03, 2024

Tania, Y. (2017). Pengaruh Gaya Kepemimpinan Transformasional dan Motivasi Kerja terhadap Kinerja Karyawan pada PT. Premier Management Consulting. Agora, 5(1), $1-8$.

Thamrin, H. M. (2012). The Influence of Transformational Leadership andOrganizational Commitment on Job Satisfaction andEmployee Performance. International Journal of Innovation, Management and Technology, 3(5).

Wahyu Ariani, D. (2013). The Relationship between Employee Engagement, Organizational Citizenship Behavior, and Counterproductive Work Behavior. International Journal of Business Administration, 4(2), 46-56.

Warrick, D. D. (2011). The Urgent Need for Skilled Transformational Leaders : Integrating Transformational Leadership and Organization Development. 8(5), 11-27.

David Oloan Sitorus. The Relationship Between Transformational Leadership, Training, and Employee Involvement as an Intervention Variable on Employee Performance 